\title{
FINITE-DIFFERENCE MODELLING OF SELF-PROPAGATING HIGH-TEMPERATURE SYNTHESIS OF MATERIALS
}

\author{
C. R. BOWEN $\dagger$ and B. DERBY \\ Department of Materials, University of Oxford, Parks Road, Oxford OX1 3PH, England
}

(Received 18 June 1994)

\begin{abstract}
The modelling of self-propagating high-temperature reactions is attempted using a finite difference model. The model is described and model results are compared with experimentally observed combustion wave velocities for the reaction $3 \mathrm{TiO}_{2}+4 \mathrm{Al}+3 \mathrm{C} \rightarrow 3 \mathrm{TiC}+2 \mathrm{Al}_{2} \mathrm{O}_{3}$ using various processing parameters (diluents, preheating etc.). The model is extended to derive a parameter which determines under what conditions a reaction will become self-propagating.
\end{abstract}

\section{INTRODUCTION}

Self-propagating high-temperature synthesis (SHS) is a ceramic processing technique whereby highly exothermic reactions are used to produce a variety of ceramic materials [1]. When an SHS reaction is initiated in one area of a reactant mixture, e.g. with a resistively heated tungsten wire, there is sufficient heat release that the reaction becomes self-propagating. A high temperature combustion wave travels along the reactants converting them to the required products. The potential advantages are that the process requires little energy and the processing time is reduced to seconds [2]. In addition the high temperature of the combustion wave tends to expel many volatile impurities so that SHS produced materials are generally of high purity [3]. One of the major disadvantages of the process is that SHS produced ceramics are of high porosity unless some means of densification, e.g. hot pressing, is employed concurrently [4].

Although there are many reports on the production of ceramic materials by SHS, little work has been carried out on modelling the combustion wave and the influence of processing parameters on it. Merzhanov [5] and Novozhilov [6] derived an analytical expression for the combustion wave which was dependant on the activation energy $(E)$ of the reaction. Hardt and Phung [7] developed a model where the rate of the reaction was determined by the time required for the reactant atoms in adjacent particles to diffuse through the product which formed between them. The wave velocity was said to be dependent on the activation energy for diffusion $(Q)$ and the diffusion coefficient $(D)$. Both of these models require a

†Present address for correspondence at: School of Materials, University of Leeds, Leeds LS2 9JT, England. knowledge of parameters which are not easily available for a particular reaction and are not easily calculated.

A more recent approach to modelling SHS employed finite-difference heat flow calculations which have been used with some success to calculate combustion wave velocities for the $\mathrm{Ti}+\mathrm{C} \rightarrow \mathrm{TiC}$ reaction [8-10]. The aim of this paper is to examine whether a finite difference method can estimate wave velocities and temperature profiles for the aluminothermic reaction

$$
\begin{gathered}
3 \mathrm{TiO}_{2}+4 \mathrm{Al}+3 \mathrm{C} \rightarrow 3 \mathrm{TiC}+2 \mathrm{Al}_{2} \mathrm{O}_{3} \\
\Delta H_{\mathrm{r}, 298}=-357.4 \mathrm{~kJ} / \mathrm{mol}\left(\mathrm{TiO}_{2}\right) .
\end{gathered}
$$

The model will be used to estimate the combustion wave velocity and examine the time-temperature history of the reactants and products. The information gained from the model will allow a greater understanding of the SHS process. The influence of processing parameters such as the effect of diluents and preheating will be compared to experimental observations. In addition, the model will be used to explore the conditions for which SHS is possible. This can be expressed in a simple parameter space with a map defining regions where SHS occurs, or is not possible.

\section{THE FINITE-DIFFERENCE MODEL}

A reaction will become self-propagating when there is sufficient heat release by the reaction to ignite reactants ahead of the reaction zone. The basis of the model is to try and emulate the process using finitedifference mathematics.

The model considers the reactants as a onedimensional array of cells which are initially at room temperature. The reaction is initiated by setting the first two cells of the array to the combustion 


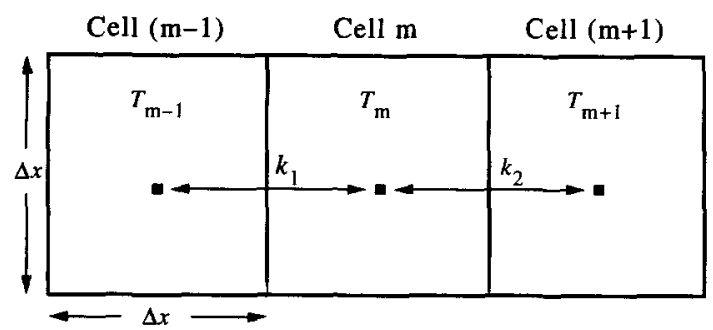

Fig. 1. Three adjacent cells $(m-1, m, m+1)$ in the finite difference model.

temperature to imitate rapid heating by an external heat source. Two cells are used as initiators because cooling of the first cell by convection and radiation is considered. If only the first cell is used to initiate the reaction it is possible for the cell to cool before it initiates an SHS wave.

After the first two cells are set at the combustion temperature, heat flow between the cells begins to heat up the reactants in the third cell. Once the reactants in the third cell reach the ignition temperature, i.e. the temperature at which the reaction begins to propagate, it is instantaneously converted to products at the combustion temperature. The fourth cell begins to heat up and the process continues so that a combustion wave travels along the model cells. The model therefore assumes that the rate of reaction is limited by heat transfer only and that reaction kinetics and transport by diffusion play a limited role.

Heat flow calculations are carried out using an energy balance approach [11]. Consider three adjacent cells $(m-1, m$ and $m+1)$ in Fig. 1, which are at temperatures $T_{\mathrm{m}-1}, T_{\mathrm{m}}$ and $T_{\mathrm{m}+1}$ respectively. The rate of change of temperature of cell $m$ is dependent on the rate of heat flow into (or out of) the cell through its two neighbours. The explicit finite-difference equation for the system is defined below [equation (2)], where the left side of the equation is the rate of heat flow into cell $m$ and the right side of the equation is the rate of temperature change of cell $m$

$$
\begin{aligned}
k_{1} \cdot A \cdot & \frac{\left[T_{\mathrm{m}-1}(t)-T_{\mathrm{m}}(t)\right]}{\Delta x}+k_{2} \cdot A \cdot \frac{\left[T_{\mathrm{m}+1}(t)-T_{\mathrm{m}}(t)\right]}{\Delta x} \\
& =\rho \cdot A \cdot \Delta x \cdot C_{\mathrm{p}} \cdot \frac{\left[T_{\mathrm{m}}(t+\Delta t)-T_{\mathrm{m}}(t)\right]}{\Delta t}
\end{aligned}
$$

where

$$
\begin{aligned}
k_{1}= & \text { thermal conductivity between cell } \\
& \mathrm{m}-1 \text { and } \mathrm{m} \text { so that } \\
& k_{1}=2 \cdot\left(k_{\mathrm{m}-1} \cdot k_{\mathrm{m}}\right) /\left(k_{\mathrm{m}-1}+k_{\mathrm{m}}\right) \\
k_{2}= & \text { thermal conductivity between cell } \\
& \mathrm{m}+1 \text { and } \mathrm{m}\left(\mathrm{J} \mathrm{s}^{-1} \mathrm{~m}^{-1} \mathrm{~K}^{-1}\right) \\
C_{\mathrm{p}}= & \text { heat capacity of cell }\left(\mathrm{J} \mathrm{kg}^{-1} \mathrm{~K}^{-1}\right) \\
\rho= & \text { density of cell }\left(\mathrm{kg} \mathrm{m}^{-3}\right) \\
\Delta x= & \text { cell dimension }(\mathrm{m}) \\
\Delta t= & \text { time increment between calculations }(\mathrm{s}) \\
A= & \text { cross sectional area of cell }\left(\mathrm{m}^{2}\right) \\
T_{\mathrm{m}}(t)= & \text { temperature of cell } \mathrm{m} \text { at time } t(\mathrm{~K}) \\
T_{\mathrm{m}}(t+\Delta t)= & \text { temperature of cell } \mathrm{m} \text { at time } t+\Delta t \\
& \text { (K). }
\end{aligned}
$$

Rearranging equation (2) allows the calculation of the temperature of cell $\mathrm{m}$ at time $(t+\Delta t)$ by knowing the temperature of the cells $(m-1, m$ and $m+1)$ at time $t$.

$$
\begin{aligned}
T_{\mathrm{m}}(t+\Delta t)-T_{\mathrm{m}}(t)= & \frac{\Delta t}{(\Delta x)^{2} \cdot C_{\mathrm{p}} \cdot \rho}\left\{k _ { 1 } \cdot \left[T_{\mathrm{m}-1}(t)\right.\right. \\
& \left.-T_{\mathrm{m}}(t)\right]+k_{2} \cdot\left[T_{\mathrm{m}+1}(t)\right. \\
& \left.\left.-T_{\mathrm{m}}(t)\right]\right\} .
\end{aligned}
$$

The first cell in the array, as it has only one nearest neighbour, is allowed to cool by convection and radiation on its exposed side, so the equation for the cell is

$$
\begin{gathered}
\epsilon \cdot \sigma \cdot A \cdot\left[298^{4}-T_{1}^{4}(t)\right]+h \cdot A \cdot\left[298-T_{1}(t)\right] \\
+k_{2} \cdot A \cdot \frac{\left[T_{1}(t)-T_{2}(t)\right]}{\Delta x} \\
=\rho \cdot \Delta x \cdot C_{\mathrm{p}} \frac{\left[T_{1}(t+\Delta t)-T_{1}(t)\right]}{2 \Delta t}
\end{gathered}
$$

where $\epsilon$ is the emissivity of the material, $\sigma$ is theStefan-Boltzman constant and $h$ is the heat convection coefficient.

A computer program was written to carry out the calculations for a row of a 100 cells at time intervals $\Delta t$. The reactant cells had the thermophysical properties of the $3 \mathrm{TiO}_{2}+4 \mathrm{Al}+3 \mathrm{C}$ powder mixture. Once a reactant cell reached the ignition temperature it was instantly converted to the combustion temperature and given the thermophysical properties of the $3 \mathrm{TiC}+2 \mathrm{Al}_{2} \mathrm{O}_{3}$ product. The cell size was the approximate value of the smallest reactant unit, which was taken as $15 \mu \mathrm{m}$ (considering $10 \mu \mathrm{m} \mathrm{Al}$ particles surrounded by sufficient smaller sized $0.63 \mu \mathrm{m} \mathrm{TiO}$ and $0.02 \mu \mathrm{m} \mathrm{C}$ particles to cause a complete reaction).

\section{MODEL PARAMETERS}

From the heat transfer equations, it can be seen that in order to model the SHS reaction the parameters of combustion temperature, ignition temperature, specific heat capacity, density and thermal conductivity of the reactants and products must be estimated.

\subsection{Specific heat capacity, density, combustion tem- perature and ignition temperature}

The specific heat and theoretical density of the reactants and products are available in the

Table 1. Comparison of calculated thermal conductivity (50\% theoretical density) with literature values

\begin{tabular}{lcc}
\hline Powder (particle size) & $\begin{array}{c}\text { Calculated } k \\
\left(\mathrm{~W} \mathrm{~m}^{-1} \mathrm{~K}^{-1}\right)\end{array}$ & $\begin{array}{c}\text { Literature } k \\
\left(\mathrm{~W} \mathrm{~m}^{-1} \mathrm{~K}^{-1}\right)\end{array}$ \\
\hline $\mathrm{TiO}_{2}(0.63 \mu \mathrm{m})$ & 0.079 & $0.068[17]$ \\
$\mathrm{Al}(10 \mu \mathrm{m})$ & 0.291 & $0.256[17]$ \\
Carbon black $(0.02 \mu \mathrm{m})$ & 0.015 & $0.020[18]$ \\
\hline
\end{tabular}


literature $[12,13]$. The theoretical density of the products $\left(4360 \mathrm{~kg} \mathrm{~m}^{-3}\right)$ is higher than the theoretical density of the reactants $\left(3347 \mathrm{~kg} \mathrm{~m}^{-3}\right)$. However, during combustion experiments the external dimensions of the sample do not change. The apparent density of the material therefore is constant during the reaction, but porosity is generated in the sample and this is accounted for when calculating the thermal conductivity of the reactants and products.

The combustion temperature of the propagating wave can be estimated by calculating the adiabatic combustion temperature $\left(T_{\mathrm{ad}}\right)$ which is calculated assuming that the enthalpy of the reaction $\left(\Delta H_{r, 298}\right)$ heats up the products and that no energy is lost to the surrounding environment. From the definition of heat capacity equation (5) allows $T_{\text {ad }}$ to be calculated.

$$
\begin{gathered}
-3 \Delta H_{\mathrm{r}, 298}=\int_{298}^{2323} C_{\mathrm{p}}\left(3 \mathrm{TiC}+2 \mathrm{Al}_{2} \mathrm{O}_{3}\right) \mathrm{d} T \\
+\Delta H_{\mathrm{m}}\left(2 \mathrm{Al}_{2} \mathrm{O}_{3}\right)+\int_{2323}^{T_{\mathrm{ad}}}\left(3 \mathrm{TiC}+2 \mathrm{Al}_{2} \mathrm{O}_{3(\mathrm{liq})}\right) \mathrm{d} T
\end{gathered}
$$

$\Delta H_{\mathrm{m}}\left(2 \mathrm{Al}_{2} \mathrm{O}_{3}\right)$ is the enthalpy of fusion of alumina which is included as $T_{\text {ad }}$ is calculated to be $2390 \mathrm{~K}$ which is higher than the melting point of alumina (2323 K).

The ignition temperature $\left(T_{\mathrm{ig}}\right)$ has been determined by differential thermal analysis to be $1173 \mathrm{~K}$ [14]. This ignition temperature also corresponds to the temperature at which a "thermal explosion" takes place, i.e. when the reactants are heated in a furnace to the ignition temperature so that the reaction takes place throughout the whole sample at the same time rather than by a propagating wave [15].

\subsection{Thermal conductivity of the reactant powder mix- ture}

Thermal conductivity data for solid materials are available in reference tables, however, there is little data on the thermal conductivity of powders and powders mixtures. A model developed by Luikov et al. [16], which had been shown to predict the thermal conductivity of a variety of metal and ceramic powders, was used.

The basis of the model is to calculate the effective conductivity of a powder by estimating the contribution of the four independent modes of heat transfer which can occur in a powder mixture. These modes are

(a) heat conduction directly through particle contacts

(b) heat conduction through the gas phase between the particles

(c) radiative heat transfer between particle surfaces

(d) gas convection in pores (only important in pores larger than several millimetres).

The model requires values of density, particle size, elastic modulus (to calculate the contact area between particles) and the thermal conductivity of the gas phase and solid material. Table 1 lists the calculated values of $k$ for the three powders compounds which compare well with values obtained from literature (although the literature values are of unknown particle size and slightly different densities).

The thermal conducitivity of a stoichiometric reactant mixture of $3 \mathrm{TiO}_{2}+4 \mathrm{Al}+3 \mathrm{C}$ is related to the thermal conductivity of the separate components and the detailed structure of the mixture. On mixing of the titania, aluminium and carbon it was observed that the mixture is black due to the carbon phase, which has the smallest particle size, coating the titania and aluminium powder. The thermal conductivity of the powder mixture was therefore calculated by an equation derived by Brailsford and Major [equation (6)] which calculates the thermal conductivity of a three phase mixture assuming that one phase is continuous [19], which in this case is the carbon black.

$$
k=\frac{k_{0} v_{0}+k_{1} v_{1} \frac{3 k_{0}}{\left(2 k_{0}+k_{1}\right)}+k_{2} v_{2} \frac{3 k_{0}}{\left(2 k_{0}+k_{2}\right)}}{v_{0}+v_{1} \frac{3 k_{0}}{\left(2 k_{0}+k_{1}\right)}+v_{2} \frac{3 k_{0}}{\left(2 k_{0}+k_{2}\right)}}
$$

where

$k_{0}, k_{1}$ and $k_{2}=$ thermal conductivities of the three phases

$v_{0}, v_{1}$ and $v_{2}=$ volume fraction of each phase and phase 0 is the continuous phase.
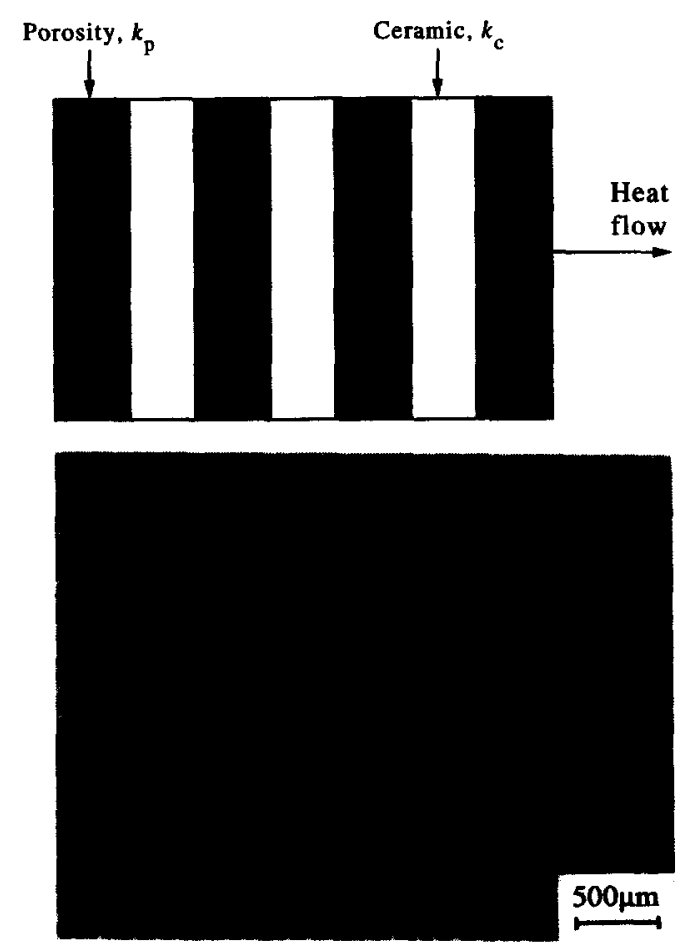

Fig. 2. (a) Idealised microstructure as alternating layers of porosity and ceramic. (b) Optical micrograph of $\mathrm{TiC}-\mathrm{Al}_{2} \mathrm{O}_{3}$ formed by SHS. Dark area is porosity, light area is ceramic. 


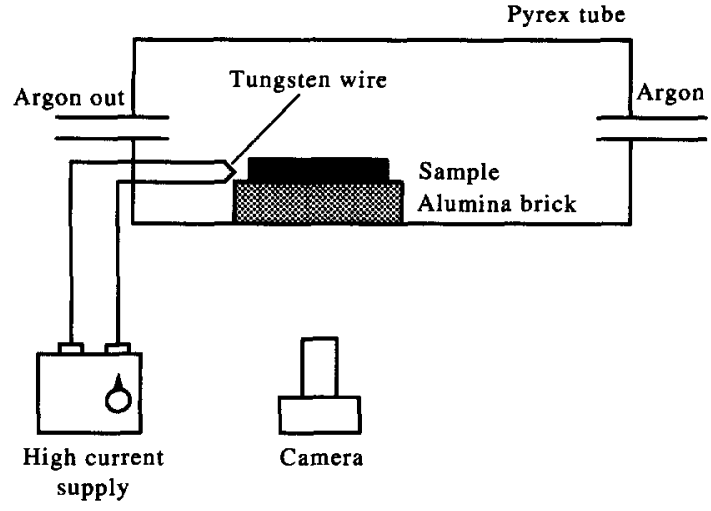

Fig. 3. Experimental apparatus to provide and inert atmosphere during combustion wave velocity measurements.

Using the values of thermal conductivity calculated by the model the thermal conductivity of the stoichiometric mixture was determined as $0.081 \mathrm{~W} \mathrm{~m}^{-1} \mathrm{~K}^{-1}$. The variation of thermal conductivity with temperature to the ignition temperature was neglected in the model because during SHS reactions gases and volatile species are violently expelled. As the effective thermal conductivity of a powder is dominated by conduction in the gas phase the accurate determination of thermal conductivity close to the reaction zone would be extremely difficult.

\subsection{Thermal conductivity of the $\mathrm{TiC}-\mathrm{Al}_{2} \mathrm{O}_{3}$ product}

It has been observed that the final microstructure of the $\mathrm{TiC}-\mathrm{Al}_{2} \mathrm{O}_{3}$ consists of an alternating laminar structure of ceramic and porosity, shown by the idealised structure in Fig. 2. If we consider heat flow in the direction shown then heat conduction is dependent on the poorer conductor. The overall thermal conducitivity of the material $\left(k_{\mathrm{m}}\right)$ is [20]
Table 2. Calculated and measured combustion temperatures and wave velocity

\begin{tabular}{lcc}
\hline & $\begin{array}{c}\text { Combustion } \\
\text { temperature }(\mathrm{K})\end{array}$ & $\begin{array}{c}\text { Wave velocity } \\
\left(\mathrm{mm} \mathrm{s}^{-1}\right)\end{array}$ \\
\hline Model & 2390 & 5.8 \\
Experimental & $2200 \pm 200$ & $3.2 \pm 0.2$ \\
\hline
\end{tabular}

$$
k_{\mathrm{m}}=\frac{k_{\mathrm{c}} \cdot k_{\mathrm{p}}}{\left(v_{\mathrm{p}} \cdot k_{\mathrm{c}}+v_{\mathrm{c}} \cdot k_{\mathrm{p}}\right)}
$$

where

$k_{\mathrm{c}}$ and $k_{\mathrm{p}}=$ thermal conductivity of the ceramic and pore phases respectively;

$v_{\mathrm{c}}$ and $v_{\mathrm{p}}=$ volume fractions of ceramic pore phases respectively.

As $k_{\mathrm{c}} \gg k_{\mathrm{p}}$ then, equation (7) reduces to

$$
k_{\mathrm{m}} \approx \frac{k_{\mathrm{p}}}{v_{\mathrm{p}}} .
$$

The thermal conductivity of the pore phase is a combination of the conductivity of the gas phase in the pore and the radiation across the pore surface [20] (convection is only important in very large pores several millimetres in size). Therefore

$$
k_{\mathrm{p}}=k_{\mathrm{gas}}(T)+4 d_{\mathrm{p}} \cdot \sigma \cdot \epsilon \cdot T^{3}
$$

where

$k_{\text {gas }}(T)=$ thermal conductivity of gas phase at temperature $T$;

$d_{\mathrm{p}}=$ pore size

\section{EXPERIMENTAL PROCEDURE}

Powder blends of $\mathrm{TiO}_{2}$ (particle size $0.63 \mu \mathrm{m}$, $98.7 \%$ purity from Johnson Matthey), $\mathrm{Al}(10.0 \mu \mathrm{m}$, $99.7 \%, A L P O C O)$ and carbon black $(\sim 0.02 \mu \mathrm{m}$,

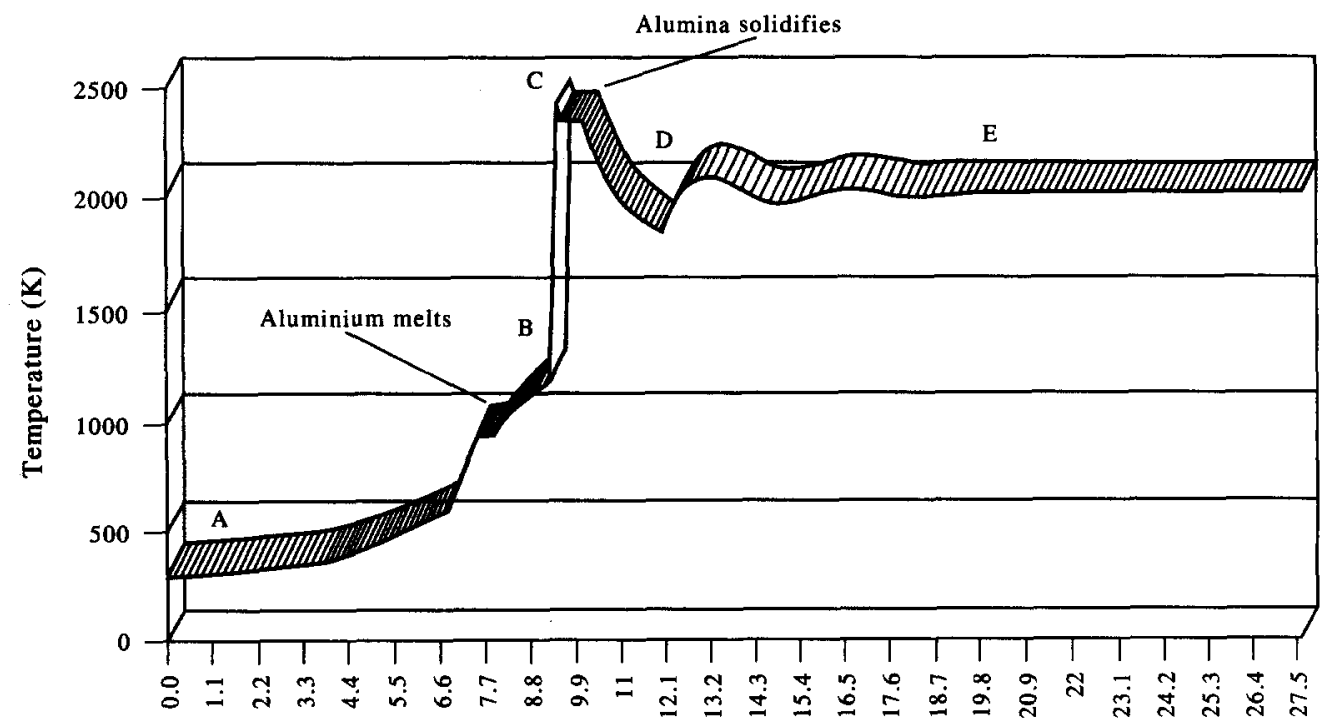

Time (ms)

Fig. 4. Time-temperature profile of a single cell in the finite difference model. 


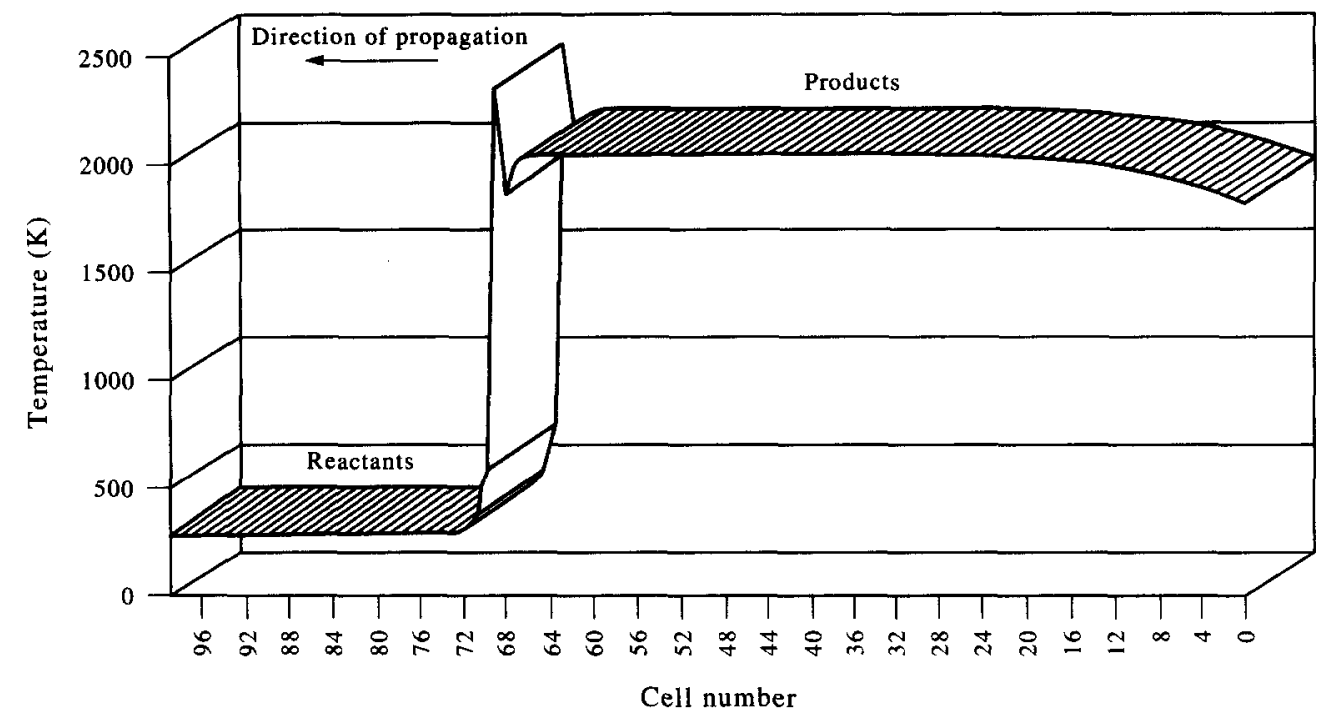

Fig. 5. Temperature profile through 100 cells at a time $t$ showing the high temperature gradient between the reactants and products.

CABOT-Elftex 285) were produced by dry ball milling the powders with alumina media for $12 \mathrm{~h}$. The reactant mixture was then sieved through a $100 \mu \mathrm{m}$ mesh to reduce the number of agglomerates. Compacts $25 \mathrm{~mm}$ in diameter and $5 \mathrm{~mm}$ thickness were prepared by cold pressing at $40 \mathrm{MPa}$ to approx. $50 \%$ theoretical density. To reduce the amount of impurities expelled during the high temperature reaction the compacts were baked at $120^{\circ} \mathrm{C}$ (in air) for $24 \mathrm{~h}$ to reduce the level of adsorbed water.

In order to provide an inert atmosphere during propagation of the combustion wave the reaction was carried out in a Pyrex reaction vessel with an argon atmosphere (Fig. 3). The argon flow rate was controlled by a valve and monitored with an oil bubbler. The sample was placed on a porous alumina brick and the reaction was initiated by means of a tungsten wire $(0.38 \mathrm{~mm}$ diameter $)$ heated by a high current supply. During synthesis the argon flow rate was reduced to a minimum to decrease the possible

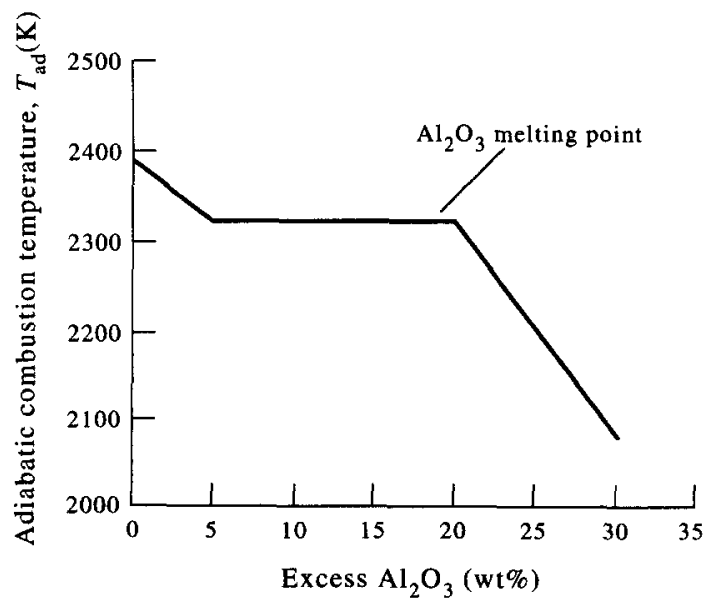

Fig. 6. Graph of adiabatic combustion temperature vs alumina diluent content. cooling of the product by the gas flow. A camera with a high speed motor drive ( 2.5 frames $/ \mathrm{s})$ was used to measure the combustion wave velocity. Combustion wave velocities were measured from a minimum of three experimental runs.

The combustion wave temperature was measured using a Kellar PB06 digital pyrometer of the disappearing filament type. The accuracy of the measurement is low (estimated as $\pm 200 \mathrm{~K}$ ) due to the difficulty in measuring the temperature of a moving combustion wave.

\section{MODEL RESULTS AND COMPARISON WITH EXPERIMENTAL DATA}

Figure 4 shows a typical time-temperature profile for a single cell. In the region $\mathrm{A} \rightarrow \mathrm{B}$ the reactants are gradually heated by the advancing combustion wave and the aluminium phase melts. On reaching the ignition temperature there is a rapid temperature increase as the reactants are converted to products at the adiabatic combustion temperature (region $\mathrm{B} \rightarrow \mathrm{C}$ ). The cell then begins to cool (region $\mathrm{C} \rightarrow \mathrm{D}$ ) and the alumina phase solidifies as heat flows into the next unreacted cell. A periodic rise and fall of the cell temperature is observed in the region $\mathrm{D} \rightarrow \mathrm{E}$ which is produced by the back flow of heat as the wave advances through the following cells. Irregularities have been observed in similar regions of experimentally measured time-temperature profiles but it is uncertain if they are due to the same mechanism [4].

The combustion wave velocity was determined from the time-temperature histories of two cells a known distance apart. Table 2 compares the calculated and experimentally determined combustion wave velocity and combustion temperature. The agreement between the figures is an indication to how realistic the model and its time-temperature data are. 


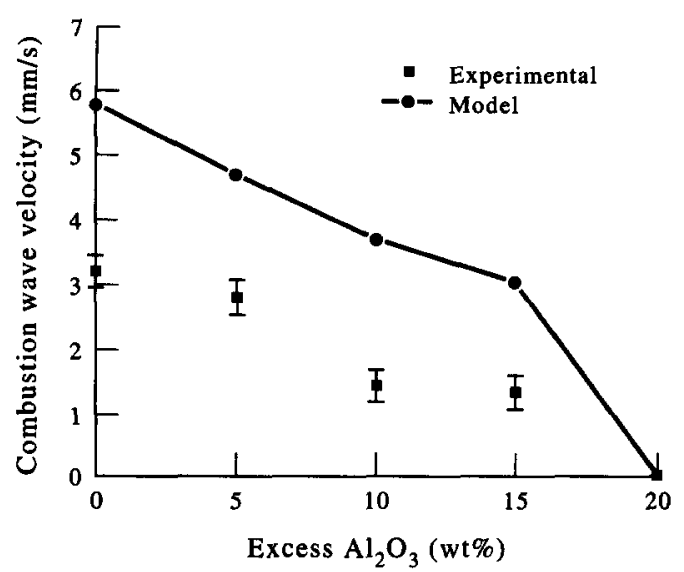

Fig. 7. Graph of combustion wave velocity vs alumina diluent content for experimental and model results.

In addition to time-temperature histories, the model is able to show the temperature distribution throughout the sample at an instantaneous time $t$, as seen in Fig. 5. The profile shows the high temperature gradient between the reactants and products that is required for the reaction to be self-sustaining. The thermal gradient can be reduced in the model by increasing the thermal conductivity of the reactants. However, if the thermal conductivity is too high then heat is rapidly drawn away from the combustion zone and the wave extinguishes itself. This effect has been noticed experimentally by Rice et al. [21] who reported that high density reactant compacts will not undergo SHS due to the high thermal conductivity of the reactant powder.

\subsection{Modelling of the addition of alumina to the reaction}

One method of attempting to control an SHS reaction is by the addition of diluents [22]. For example, alumina powder can be added to the initial reactant mixture, so that the SHS equation becomes

$$
\begin{aligned}
3 \mathrm{TiO}_{2}+4 \mathrm{Al}+3 \mathrm{C}+ & x \mathrm{Al}_{2} \mathrm{O}_{3} \\
& \rightarrow 3 \mathrm{TiC}+(2+\mathrm{x}) \mathrm{Al}_{2} \mathrm{O}_{3} .
\end{aligned}
$$

The added alumina does not take part in the reaction but merely increases the thermal mass of the reactants and thus lowers the combustion temperature. The lower combustion temperature gives rise to a lower reaction rate and thus the combustion wave velocity is reduced.

The modelling of the addition of diluent using the finite difference model is carried out by calculating the variation of thermal conductivity, specific heat capacity of reactants and products and $T_{\text {ad }}$ with alumina diluent content. The change of reactant thermal conductivity as alumina is added is low. Alumina powder was calculated by the Luikov model to have a thermal conductivity of $0.082 \mathrm{~W} \mathrm{~m}^{-1} \mathrm{~K}^{-1}$ which is similar to titania powder $\left(0.079 \mathrm{~W} \mathrm{~m}^{-1} \mathrm{~K}^{-1}\right)$. As the volume fraction of alumina increased this had little effect on the thermal conductivity of the reactants as it is dominated by the low thermal conductivity of the carbon phase. The specific heat capacity of reactant and products were calculated using thermodynamic data $[12,13]$.

Thermal conductivity and specific heat variations due to the addition of alumina will only have a small effect on the combustion wave when compared to the effect of the change of $T_{\text {ad }}$. The variation of $T_{\text {ad }}$ with alumina diluent level is shown in Fig. 6.

The experimentally measured variation of combustion wave velocity with alumina diluent content is shown in Fig. 7. As the alumina content increases the combustion wave velocity decreases. At 10 and $15 \mathrm{wt} \%$ additions of alumina the combustion wave becomes unstable and the wave velocity calculated is the mean speed over the whole sample. At $20 \mathrm{wt} \%$ excess alumina the reactants could not be ignited even though the adiabatic combustion temperature (2323 K) satisfies the empirical observation that $T_{\text {ad }}$ must be greater than $1800 \mathrm{~K}$ for SHS to occur [23]. This can be accounted for by considering that, in addition to lowering the combustion temperature, the inert alumina diluent is acting as a barrier which prevents reactant particle contact.

The finite difference model calculations are shown in Fig. 7 for comparison with experimental results. As the alumina diluent content is increased the model wave velocity decreases in a similar manner to the experimental results. Both the experimental and model fail to propagate $20 \mathrm{wt} \%$ alumina. No transition from stable to unstable propagation was observed with the model.

\subsection{Modelling of the use of excess aluminium}

Another method of controlling the SHS reaction by the addition of diluents can be achieved by the addition of excess reactants. For example excess aluminium can be added to the initial reactant mix so that the reaction becomes

$$
\begin{aligned}
3 \mathrm{TiO}_{2}+(4+\mathrm{x}) \mathrm{Al} & +3 \mathrm{C} \\
& \rightarrow 3 \mathrm{TiC}+2 \mathrm{Al}_{2} \mathrm{O}_{3}+x \mathrm{Al} .
\end{aligned}
$$

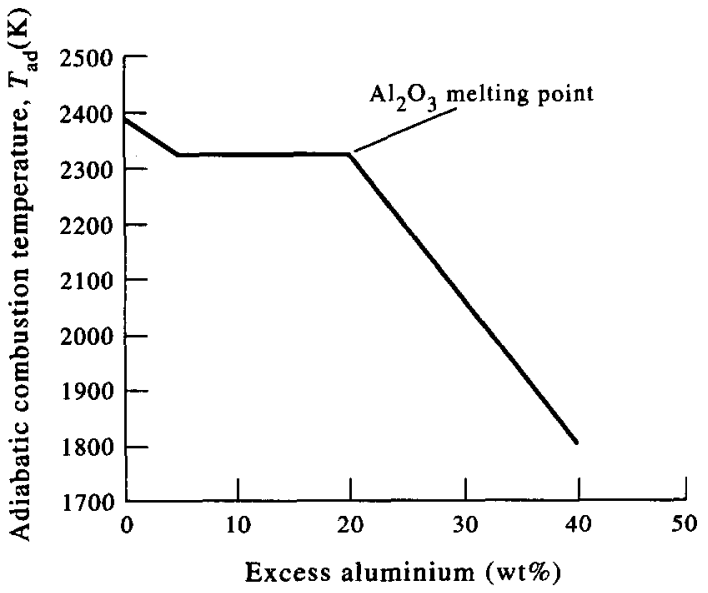

Fig. 8. Graph of adiabatic combustion temperature vs aluminium diluent content. 


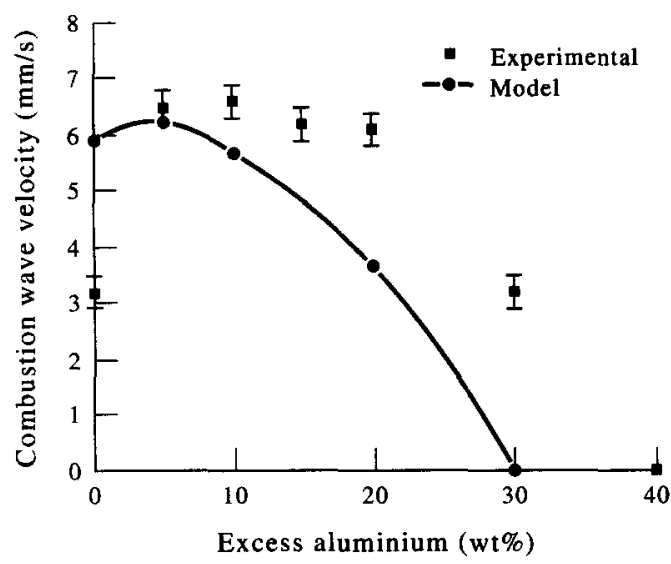

Fig. 9. Graph of combustion wave velocity vs aluminium diluent content for experimental and model results.

The finite difference modelling of the variation of wave velocity with aluminium content is carried out by calculating the change of thermal conductivity, specific heat and $T_{\text {ad }}$ with aluminium content. The thermal conductivity of the reactant powder is achieved by increasing the volume fraction of the aluminium phase in the rule of mixtures equation of Brailsford and Major. Aluminium has a greater effect on the thermal conductivity of the reactants when compared to using alumina as a diluent which is due to the much higher thermal conductivity of the aluminium powder. Although specific heat and thermal conductivity have some effect on the wave velocity the dominant factor is the change in adiabatic combustion temperature with excess aluminium content which is shown in Fig. 8.

The experimental measurements of the variation of wave velocity with aluminium content are shown in Fig. 9. It can be seen that the expected decrease of the wave velocity with increasing diluent content is not observed. The wave velocity increases with a small addition of excess aluminium $(5 \% \mathrm{wt})$ and the wave velocity begins to decrease at higher additions of diluent with the reaction failing to propagate at

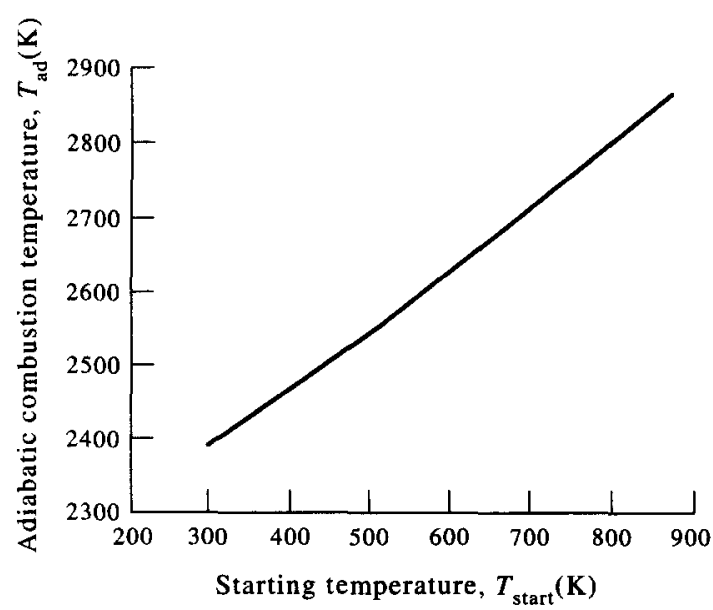

Fig. 10. Graph of adiabatic combustion temperature vs preheating (starting) temperature.

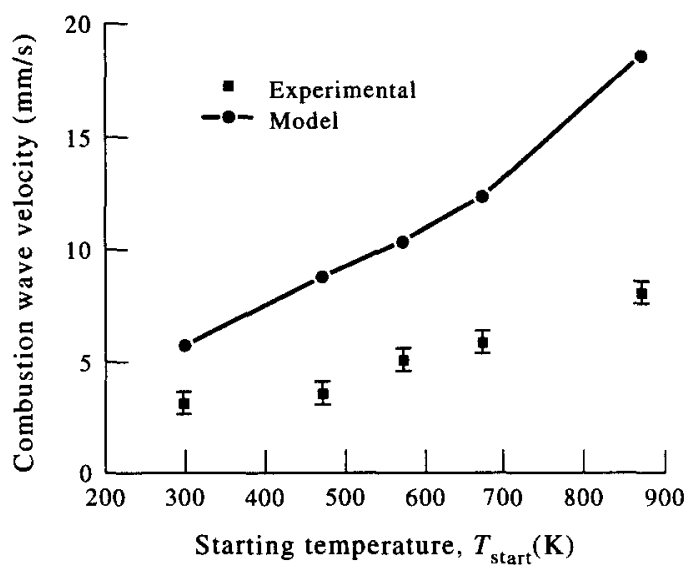

Fig. 11. Graph of combustion wave velocity vs starting temperature for experimental and model results.

$40 \%$ wt excess aluminium. An increase in wave velocity with liquid diluent has been observed for other reactions by $\mathrm{Fu}$ et al. [24] on the reaction $\mathrm{Ti}+2 \mathrm{~B}+\mathrm{xAl} \rightarrow \mathrm{TiB}_{2}+\mathrm{xAl}$ and by Feng et al. [25] on the reaction $2 \mathrm{~B}_{2} \mathrm{O}_{3}+\mathrm{C}+(4+\mathrm{x}) \mathrm{Al} \rightarrow$ $\mathrm{B}_{4} \mathrm{C}+2 \mathrm{Al}_{2} \mathrm{O}_{3}+\mathrm{xAl}$.

The possible reasons for the increased combustion wave velocity could be

(i) increased mass diffusion and transfer due to presence of a liquid phase [24]

(ii) increased thermal conductivity of reactants as more aluminium is added

(iii) increased aluminium/titania particle content.

The effect of increased thermal conductivity is taken into account by the finite difference model. Figure 9 shows that the finite difference model predicts only a small initial increase of the wave velocity with aluminium content. At higher levels of diluents the model wave velocity begins to decrease gradually and fails to propagate at $30 \mathrm{wt} \%$ excess aluminium. From the model calculations it can be assumed that the effect of thermal conductivity on the wave velocity is only a small factor which causes the experimentally observed increase in wave velocity.

Increasing the aluminium content of the reactants increases aluminium/titania particle contact. This may result in an increase in wave velocity as the SHS reaction has been shown from DTA experiments to

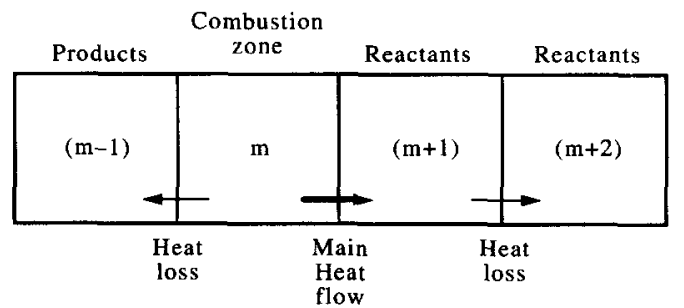

Fig. 12. Four adjacent cells in the finite different model showing the areas of heat flow from the combustion zone. The wave will continue to propagate if the combustion zone can heat the reactants in cell $(m+1)$ to the ignition temperature. 

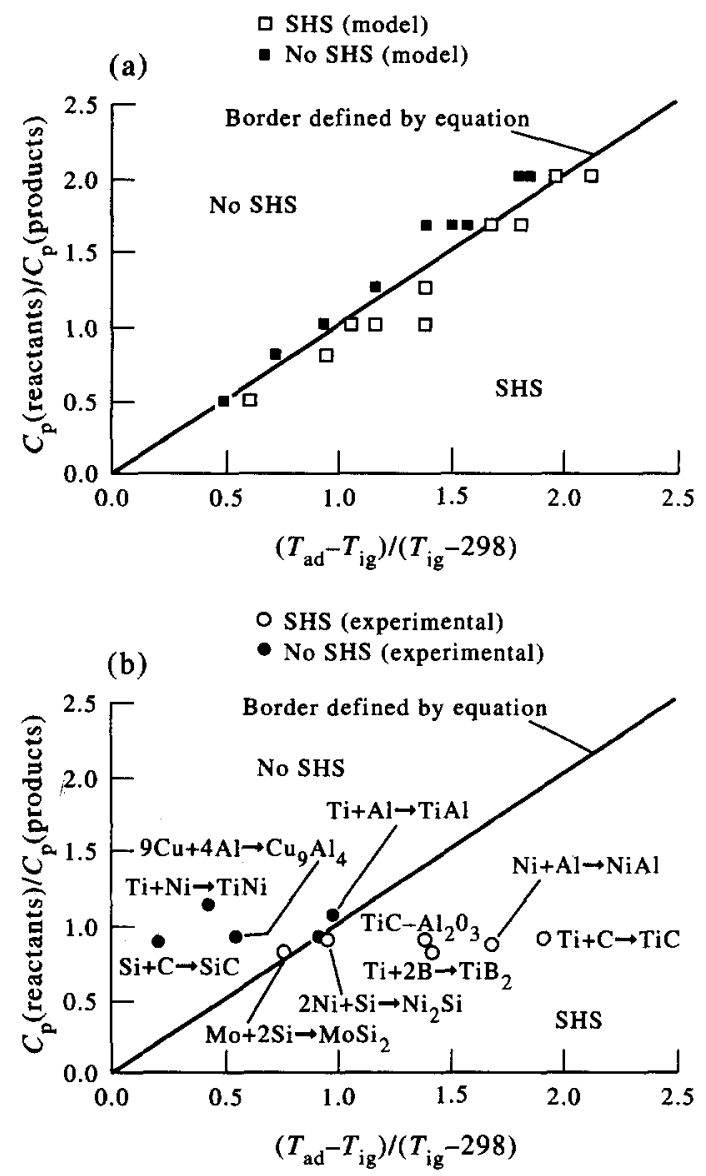

Fig. 13. (a) Graph showing areas defined as SHS and non-SHS. Model results are plotted and whether the combustion wave undergoes SHS is indicated. (b) Various reactions obtained from literature are plotted on the mapped region.

occur by an initial reaction between $\mathrm{Al}$ and $\mathrm{TiO}_{2}$ [14] However, Fu et al. [24] observed a similar effect on the reaction $\mathrm{Ti}+2 \mathrm{~B}+\mathrm{xAl} \rightarrow \mathrm{TiB}_{2}+\mathrm{xAl}$ where the Al does not take part in the reaction. The reason for the experimentally observed increase in wave velocity is therefore probably due to the increased diffusion processes due to the presence of the liquid aluminium phase during the reaction. This observation shows the limitations of the finite difference model which considers that the combustion wave is limited by heat flow only and does not consider local chemical kinetics.

It is interesting to note that Feng et al. [26] conducted similar experiments on reaction 11 but observed only a decrease in wave velocity with aluminium content. This could be due to the fact that Feng et al. used very much larger particle size reactants (all $44 \mu \mathrm{m}$ ). The increased diffusion processes due to the presence of liquid aluminium may have had little effect as the reaction rate was dominated by large diffusion barriers which were produced as the products formed between the large particles.

\subsection{Modelling the effect of preheating the reactants prior to ignition}

Whereas diluents are used to decrease the combustion temperature, preheating the reactants prior to ignition produces an increase in the combustion temperature and reaction rate [27]. The effect of preheating on the adiabatic combustion temperature is estimated by considering the energy supplied by the reaction and the energy supplied by the preheating process.

Enthalpy of reaction + energy supplied by heating $=$ energy required to heat up products

$$
\begin{array}{r}
-3 \Delta H_{\mathrm{r}, 298}+\int_{298}^{T_{\text {sart }}} C_{\mathrm{p}}\left(3 \mathrm{TiO}_{2}+4 \mathrm{Al}+3 \mathrm{C}\right) \mathrm{d} T \\
=\int_{298}^{T_{\mathrm{ad}}} C_{\mathrm{p}}\left(3 \mathrm{TiC}+2 \mathrm{Al}_{2} \mathrm{O}_{3}\right) \mathrm{d} T .
\end{array}
$$

Where $T_{\text {start }}$ is the preheat temperature of the reactants prior to ignition of the combustion wave.

Modelling the effect of preheating on the combustion wave velocity is achieved by increasing the starting temperature of the reactant cells to $T_{\text {start }}$ and increasing the adiabatic combustion temperature which has been calculated using equation (12) and is shown in Fig. 10. Figure 11 is a graph of wave velocity vs preheating temperature for the model and experimental results. Both the model and experimental wave velocity increase with starting temperature although the difference between the predicted and measured wave velocity becomes larger as the preheating temperature increases. This may be an effect of the increased radiative heat losses which occur from the sample edges as the combustion temperature of the reaction increases. In addition the specific heat capacity equations are only accurate in the temperature range $298-1800 \mathrm{~K}$ and therefore the higher the extrapolation (up to $2900 \mathrm{~K}$ ) the greater the possibility or error. Errors in the specific heat capacity $\left(C_{\mathrm{p}}\right)$ calculations may have a large effect on the model wave velocity as $C_{\mathrm{p}}$ is used in both the calculation of $T_{\text {ad }}$ and in the heat transfer calculations in the finite-difference model.

Advani et al. [10] used the finite difference method to model preheating of the $\mathrm{Ti}+\mathrm{C} \rightarrow \mathrm{TiC}$ reaction and obtained very good agreement with their experimental work up to $850^{\circ} \mathrm{C}$. During preheating from 200 to $850^{\circ} \mathrm{C}$ the adiabatic combustion temperature remains at the melting point of $\mathrm{TiC}(3210 \mathrm{~K})$ and the melt fraction of $\mathrm{TiC}$ increased from 0 to $60 \%$. It was stated that the increase in model wave velocity with temperatures from 200 to $850^{\circ} \mathrm{C}$ appeared to be only due to an increase in the initial cell temperature as the energy released during solidification of the $\mathrm{TiC}$ was not included in the model. The energy released by the liquid phase has a significant effect on the wave velocity. If the energy contribution of the $\mathrm{TiC}$ melt was included in the model larger discrepancies between predicted and measured wave velocities would be observed. 


\section{THE CONDITIONS NECESSARY FOR SHS}

The finite difference model appears to be able to model SHS reactions, therefore, the model could be used to provide information on the type of reaction which will undergo SHS. For instance, which particular values of $T_{\mathrm{ad}}, T_{\mathrm{ig}}, C_{\mathrm{p}}, k$ and $\rho$ combine to produce an SHS reaction? By mapping an appropriate parameter space it is possible to illustrate the reactions which can undergo SHS.

Consider four cells as in Fig. 12, where cell $m$ has just reacted and is at the adiabatic combustion temperature and cell $m+1$ is beginning to heat up to the ignition temperature. The reaction will proceed if the energy released by cell $\mathrm{m}$ on cooling is greater than the energy required to heat up cell $\mathrm{m}+1$ to $T_{\mathrm{ig}}$. In addition there will be heat losses from cell $\mathrm{m}$ to cell $m-1$ (the back flow discussed earlier), and from cell $m+1$ to cell $m+2$ through the reactants.

Therefore we can define that a reaction will undergo an SHS reaction if

$$
\begin{aligned}
& \int_{T_{\mathrm{ig}}}^{T_{\mathrm{ad}}} C_{\mathrm{p}} \text { (products) } \mathrm{d} T-\text { heatloss }_{\mathrm{m} \rightarrow \mathrm{m}-1} \\
& \geqslant \int_{T_{\text {slart }}}^{T_{\mathrm{ig}}} C_{\mathrm{p}} \text { (reactants) } \mathrm{d} T+\text { heatloss }_{\mathrm{m}+1 \rightarrow \mathrm{m}+2}
\end{aligned}
$$

where $T_{\text {start }}$ is the starting temperature of the reactants (usually $298 \mathrm{~K}$, unless some preheating is used). The range $T_{\mathrm{ig}}$ to $T_{\mathrm{ad}}$ has been used on the left hand side of equation (13) because if the temperature of the combustion zone falls below $T_{\text {ig }}$ then it will be impossible for it to heat the reactants up to $T_{\mathrm{ig}}$.

It has been observed that the SHS reaction is only influenced by very high values of reactant thermal conductivity. Under normal conditions the thermal gradient between reactants and products is very large due to the low thermal conductivity of the reactant powder and therefore heat flow through the reactants is small and can be neglected. Similarly the back flow of heat through the products is low (see temperature profiles in Figs 4 and 5) because the temperature difference throughout the high temperature product is small. Considering a reaction with no solidification or melting, equation (13) can be simplified to

$$
\int_{T_{\mathrm{gg}}}^{T_{\mathrm{ad}}} C_{\mathrm{p}} \text { (products) } \mathrm{d} T \geqslant \int_{T_{\mathrm{start}}}^{T_{\mathrm{ig}}} C_{\mathrm{p}} \text { (reactants) } \mathrm{d} T .
$$

On integrating

$$
\begin{aligned}
\left.\bar{C}_{\mathrm{p}} \text { (products) }\right) & \left(T_{\mathrm{ad}}-T_{\mathrm{ig}}\right) \\
& \geqslant \bar{C}_{\mathrm{p}}(\text { reactants }) \cdot\left(T_{\mathrm{ig}}-T_{\text {start }}\right)
\end{aligned}
$$

where $\bar{C}_{p}$ is the mean specific heat capacity in the temperature ranges.

Rearranging the equation, SHS will occur if

$$
\frac{\left(T_{\mathrm{ad}}-T_{\mathrm{ig}}\right)}{\left(T_{\mathrm{ig}}-T_{\text {start }}\right)} \geqslant \frac{\left.\bar{C}_{\mathrm{p}} \text { (reactants }\right)}{\left.\bar{C}_{\mathrm{p}} \text { (products }\right)} .
$$

Equation (16) includes all the parameters used in the model except for density and thermal conductivity, which are only factors under extreme circumstances.

A wide range of values of $T_{\mathrm{ad}}, T_{\mathrm{ig}}, T_{\mathrm{start}}$ and specific heat ratios were used in the model and plotted on the graph of $\left(T_{\text {ad }}-T_{\mathrm{ig}}\right) /\left(T_{\mathrm{ig}}-T_{\text {start }}\right)$ vs $\mathrm{C}_{\mathrm{p}}$ (reactants) $/ \mathrm{C}_{\mathrm{p}}$ (products) as shown in Fig. 13(a). The diagonal line is the focus of equation (16) and divides the mapped region into an area where SHS is possible and another area where it is not. There is an excellent agreement with the prediction of the complete finite difference model.

In order to validate the model experimental results it is necessary to obtain $T_{\text {ig }}$ experimentally, all other parameters can be either found in the literature or calculated. A variety of reactions were found in the literature in which the ignition temperature has been obtained by thermocouple measurements, differential thermal analysis or by noting the furnace temperature in the "thermal explosion" method. These reactions are listed in Table 3.

The data in Table 3 is shown graphically in Fig. 13(b), were the ability of the reaction to undergo SHS was predicted correctly for every reaction, except for $\mathrm{Mo}+2 \mathrm{Si} \rightarrow \mathrm{MoSi}_{2}$ which is a weakly exothermic reaction. It is observed that the very exothermic SHS reactions (such as $\mathrm{Ti}+\mathrm{C} \rightarrow \mathrm{TiC}$ ) lie well within the SHS boundary and that weaker SHS reactions which propagate slowly or are unstable, such as $2 \mathrm{Ni}+\mathrm{Si} \rightarrow \mathrm{Ni}_{2} \mathrm{Si}$ and $\mathrm{Mo}+2 \mathrm{Si} \rightarrow \mathrm{MoSi}_{2}$ lie close to the boundary line. The weak exothermic

\begin{tabular}{|c|c|c|c|c|c|}
\hline Reaction [Ref.] & $T_{\mathrm{ad}}(\mathrm{K})$ & $T_{\mathrm{ig}}(\mathrm{K})$ & $\frac{\left(T_{\mathrm{ad}}-T_{\mathrm{ig}}\right)}{\left(T_{\mathrm{ig}}-298\right)}$ & $\frac{C_{\mathrm{p}} \text { (reactants) }}{C_{\mathrm{p}} \text { (products) }}$ & SHS \\
\hline $\mathrm{Si}+\mathrm{C} \rightarrow \mathrm{SiC}[28]$ & 1800 & 1573 & 0.20 & 0.89 & No \\
\hline $\mathrm{Ti}+\mathrm{Ni} \rightarrow \mathrm{TiNi}[29]$ & 1552 & 1183 & 0.42 & 1.14 & No \\
\hline $9 \mathrm{Cu}+4 \mathrm{Al} \rightarrow \mathrm{Cu}_{9} \mathrm{Al}_{4}[30]$ & 1103 & 821 & 0.54 & 0.93 & No \\
\hline $3 \mathrm{ZrO} 2+4 \mathrm{Al}+3 \mathrm{C} \rightarrow 3 \mathrm{ZrC}+2 \mathrm{Al}_{2} \mathrm{O}_{3}[15]$ & 2000 & 1193 & 0.90 & 0.93 & No \\
\hline $\mathrm{Ti}+\mathrm{Al} \rightarrow \mathrm{TiA}][31]$ & 1518 & 913 & 0.98 & 1.05 & No \\
\hline & & & $1.12, T_{\text {start }}=373$ & 1.05 & Yes \\
\hline $\mathrm{Mo}+2 \mathrm{Si} \rightarrow \mathrm{MoSi}_{2}[32]$ & 1913 & 1217 & 0.76 & 0.82 & Yes \\
\hline $2 \mathrm{Ni}+\mathrm{Si} \rightarrow \mathrm{Ni}_{2} \mathrm{Si}[33]$ & 1600 & 965 & 0.95 & 0.91 & Yes \\
\hline $\mathrm{Ni}+\mathrm{Al} \rightarrow \mathrm{NiAl}[34]$ & 1911 & 900 & 1.68 & 0.85 & Yes \\
\hline $\mathrm{Ti}+\mathrm{C} \rightarrow \mathrm{TiC}[35]$ & 3210 & 1300 & 1.91 & 0.89 & Yes \\
\hline $\mathrm{Ti}+2 \mathrm{~B} \rightarrow \mathrm{TiB}_{2}[36]$ & 3200 & 1573 & 1.28 & 0.81 & Yes \\
\hline $3 \mathrm{TiO}_{2}+4 \mathrm{Al}+3 \mathrm{C} \rightarrow \mathrm{TiC}+2 \mathrm{Al}_{2} \mathrm{O}_{3}[15]$ & 2390 & 1173 & 1.39 & 0.89 & Yes \\
\hline
\end{tabular}
reactions, such as $\mathrm{Si}+\mathrm{C} \rightarrow \mathrm{SiC}$ and $\mathrm{Ti}+\mathrm{Ni} \rightarrow \mathrm{TiNi}$ lie well within the "No SHS" zone and the "thermal explosion" method must be used to produce a reaction.

Table 3. SHS parameters for a variety of reactions, $T_{\text {start }}=298 \mathrm{~K}$ unless indicated 
The effect of preheating on the SHS reaction $\mathrm{Ti}+\mathrm{Al} \rightarrow \mathrm{TiAl}$ can also be seen in Table 3 . It has been reported by $\mathrm{Yi}$ et al. [31] that preheating above $373 \mathrm{~K}$ is required to produce a steady SHS reaction. When $T_{\text {start }}$ is increased from 298 to $373 \mathrm{~K}$ then $\left(T_{\text {ad }}-T_{\text {ig }}\right) /\left(T_{\text {ig }}-T_{\text {start }}\right)$ becomes greater the ratio of specific heats and therefore the reaction moves from the "No SHS" zones into the "SHS" zone on the graph. Accurate prediction of the required $T_{\text {start }}$ would be difficult because of the inaccuracies of the model near the boundary conditions due to errors in the specific heat capacity calculations and ignition temperature and the simplification of the model.

\section{CONCLUSION}

Modelling of the SHS reaction $3 \mathrm{TiO}_{2}+4 \mathrm{Al}+$ $3 \mathrm{C} \rightarrow 3 \mathrm{TiC}+2 \mathrm{Al}_{2} \mathrm{O}_{3}$ has been carried out using finite-difference modelling. The model combustion wave velocity compares well with experimental observations.

Time-temperature profiles from the model reveal a periodic fluctuation in the temperature of the ceramic directly after the SHS reaction. This is caused by the back flow of heat from the advancing combustion wave. Distance-temperature profiles show the large temperature gradient between the reactants and products which is required to sustain the reaction. Increasing the thermal conducitivity of the reactants lowers the temperature gradient but can cause rapid cooling of the reaction zone resulting in the combustion wave being extinguished. This is observed experimentally with high density reactant compacts of high thermal conductivity.

Processing parameter effect such as the addition of diluents and preheating have also been modelled. Model results generally compare well with experimental results, however, the addition of aluminium as a diluent highlights the disadvantage of using a model which assumes that the wave is limited by heat transfer and that diffusion plays a limited role.

The model has allowed the effects of adiabatic combustion temperature $\left(T_{\text {ad }}\right)$, ignition temperature $\left(T_{\mathrm{ig}}\right)$, starting temperature $\left(T_{\text {star }}\right)$, specific heat $\left(C_{\mathrm{p}}\right)$ and thermal conductivity $(k)$ on the SHS wave to be examined. The information gained from the model has enabled a parameter to be derived which determines whether a reaction will undergo SHS. A reaction will become self-propagating if

$$
\frac{\left(T_{\mathrm{ad}}-T_{\mathrm{ig}}\right)}{\left(T_{\mathrm{ig}}-T_{\text {start }}\right)} \geqslant \frac{\bar{C}_{\mathrm{p}} \text { (reactants) }}{\bar{C}_{\mathrm{p}} \text { (products) }}
$$

The predictions of the equation compare well with a variety of reactions found in the literature. This kinetic condition for SHS has a sounder theoretical foundation than empirical relations which have been proposed earlier, e.g. a critical value of $T_{\text {ad }}$ or ratio of $T_{\mathrm{ad}} / C_{\mathrm{p}}$. In addition this formulation can be used to include the influence of preheating and diluents.
Acknowledgements-We would like to thank the SERC and the Cookson Group Technology Centre for providing funding for this project.

\section{REFERENCES}

1. Z. A. Munir and U. Anselmi-Tamburini, Mater. Sci. Rep. 3, 277 (1989).

2. H. C. Yi and J. J. Moore, J. Mater. Sci. 25, 1159 (1990).

3. L. J. Kecskes and A. Niiler, J. Am. Ceram. Soc. 72, 655 (1989).

4. S. D. Dunmead, Z. A. Munir, J. B. Holt and D. D. Kingman, J. Mater. Sci. 26, 2410 (1991).

5. A. G. Merzhanov, Dokl. Akad. Nauk. SSSR 233, 1130 (1977).

6. B. V. Novozhilov, Dokl. Akad. Nauk SSR 144, 1328 (1962).

7. A. P. Hardt and P. V. Phung, Combust. Flame 21, 77 (1973).

8. T. Kottke and A. Niiler, Thermal conductivity effects on SHS reactions. Technical report BRL-TR-2889. Ballistics Research Laboratory, Aberdeen Proving Ground, Md (1988).

9. A. H. Advani, N. N. Thadhani, H. A. Grebe, R. Heaps, C. Coffin and T. Kottke, Scripta metall. mater. 25, 1447 (1991).

10. A. H. Advani, N. N. Thadhani, H. A. Grebe, R. Heaps, C. Coffin and T. Kottke, J. Mater. Sci. 27, 3309 (1992).

11. Introduction to Heat Transfer (edited by F. P. Incropera and D. P. De Witt), 2nd edn. Wiley, New York (1990).

12. O. Kubashewski and C. B. Alcock, in Metallurgical Thermochemistry. Pergamon Press, New York (1979).

13. Handbook of Properties of Technical and Engineering Ceramics (edited by R. Morrel). Her Majesty's Stationery Office, London (1985).

14. C. R. Bowen and B. Derby, J. Therm. Anal. 42, 713 (1994).

15. C. R. Bowen, S. Hulsman and B. Derby, Preliminary studies on the manufacture of multiphase ceramics by SHS, 2nd European Ceramic Society Conference, p. 631. Augburg (1991).

16. A. V. Luikov, A. G. Shaskov, L. L. Vasiliev and Yu. E. Fraiman, Int. J. Heat Mass Transf. 11, 117 (1968).

17. N. N. Medvedev, J. Engng Phys. 14, 176 (1968).

18. D. B. Rogers and J. W. Williamson, Therm. Conduct. 15, 317 (1978).

19. A. D. Brailsford and K. G. Major, Br. J. appl. Phys. 15, 313 (1964).

20. W. D. Kingery, Introduction to Ceramics. Wiley, New York (1960).

21. R. W. Rice, G. Y. Richardson, J. Kunetz, T. Schroeter and W. J. McDonough, Adv. Ceram. Mater. 2, 222 (1987).

22. T. Kottke, L. J. Kecskes and A. Niiler, AIChE J. 36, $1581(1990)$.

23. N. P. Novikov, I. P. Borovinskaya and A. G. Merzhanov, in Thermodynamic Analysis of SHS Reactions. Combustion Processes in Chemical Technology and Metallurgy (edited by A. G. Merzhanov). Chernogolovka (1975).

24. Z. Y. Fu, R. Z. Yuan, Z. A. Munir and Z. L. Wang, Int. J. SHS 1, 119 (1992).

25. H. J. Feng, J. J. Moore and D. G. Wirth, Combustion synthesis of $\mathrm{B}_{4} \mathrm{C}-\mathrm{Al}_{2} \mathrm{O}_{3}-\mathrm{Al}$ composite materials. MRS Fall meeting (1991).

26. H. J. Feng, J. J. Moore and D. G. Wirth, Metall. Trans. A 23A, 2373 (1992).

27. J. B. Holt and Z. A. Munir, J. Mater. Sci. 21, 251 (1986).

28. R. Pampuch, L. Stobierski, J. Lis and M. Raczka Mater. Res. Bull, 22, 1225 (1987).

29. J. J. Moore and H. C. Yi, Mater. Sci. 24, 3449 (1989). 
30. L. L. Wang, Z. A. Munir and J. B. Holt, Metall. Trans. B 21B, 567 (1990).

31. H. C. Yi, A. Petric and J. J. Moore, J. Mater. Sci. 27, 6797 (1992)

32. S. C. Deevi, J. Mater. Sci. 26, 3343 (1991).

33. S. Zhang and Z. A. Munir, J. Mater. Sci. 27, 5789 (1992).
34. K. A. Philpot, Z. A. Munir and J. B. Holt, J. Mater. Sci. 22, 159 (1987)

35. S. C. Deevi, J. Mater. Sci. 26, 2662 (1991).

36. S. D. Dunmead and J. B. Holt, Proceedings of the DARPA/Army symposium on SHS, Daytona Beach, Fla (1985). 